\title{
White Civility and the Im/Possibility of Crossing in Guy Vanderhaeghe's The Last Crossing ${ }^{1}$
}

In his book White Civility: The Literary Project of English Canada Daniel Coleman identifies the concept of white civility as the "central organizing problematic" (6) and "the normative concept of (English) Canadianness" (4) that emerged in Canada in the late nineteenth century and to a certain extent is present in the Canadian popular consciousness even today. ${ }^{2}$

Coleman first analyzes the term civility by noting that it "combines the temporal notion of civilization as progress that was central to the idea of modernity and the colonial mission with the moral-ethical concept of a (relatively) peaceful order-that is to say, the orderly regulation between individual liberty and collective equality that has been fundamental to the politics of the modern nation state" (Coleman 10; emphasis in the original). Inherent in the notion of civility are, on one hand, the ideas of civilization as progress measured with the normative ruler of European or, more precisely, British civilization, and of enlightenment of the more backward or uncivil societies. On the other, in the civility are subsumed the notions of liberty and equality shared by the individuals belonging to the civil society, which begs the question of Others who are excluded from it for one reason or another. Coleman argues that, even though civility is a positive concept, it is structurally ambivalent because, while it "involves the creation of justice and equality, it simultaneously creates borders to the sphere in which justice and equality, are maintained" (9). The notion of civility, therefore, not only determines that which falls within its sphere and that which falls outside it, serving as a tool of self-definition through the separation from the uncivil Other, but the concept of civility also justifies the use of "uncivil violence and unfair exclusions" (9) outside its border in order to ensure justice and equality within it. Understood in this way, civility allows those societies that define themselves as civil to rationalize and justify the use of violence and suppression against societies they

\footnotetext{
"As Cormac McCarthy created a passionate tribute to the frontier between the U.S. and Mexico, Vanderhaeghe is in the process of developing an equally important 'Border' work that looks at the idea of the $49^{\text {th }}$ [parallel]." (Endicott n. pag.) In a chapter of his book Ispisivanje prostora: čitanje suvremenoga američkog romana (Writing Space: a Reading of the Contemporary American Novel) (Zagreb: 2000), Stipe Grgas examines the South-Western borderland of the American West as represented in Cormac McCarthy's Border Trilogy. My article, as homage to Professor Grgas's work, will discuss the North-Western, Canadian-U.S. borderland by analyzing one novel from Guy Vanderhaeghe's Western Trilogy.

2 The research for this article was partly funded from the project "A Cultural History of Capitalism: Britain, America, Croatia" by the Croatian Science Foundation (HRZZ-1543).
} 
proclaim as uncivil. Moreover, the very borders between civility and uncivility are interpreted as "the sites where new projects of civility are under negotiation" $(9,13)$, allowing civil societies to increase their territories as the borders are continually pushed back and new lands are claimed. This kind of rhetoric, prominent in late nineteenthcentury Canada and especially the British North-West Territories, is strongly reminiscent of Frederic Jackson Turner's frontier thesis, which celebrated the creation of the authentic American nation on the frontier between savagery and civilization, where new civility was forged by pushing aside the wilderness. While Turner used phrases such as "winning the wilderness" (2) and the "advance of the frontier" (4) to emphasize the discourse of progress and the self-begetting of the "true" American nation in the West, the emergent Canadian nation used similar rhetoric to mimic instead the already existent model of British civility.

The late nineteenth-century British North-West Territories that were in the process of becoming the Canadian Western settlement were a site "under construction" and therefore a site in-between. Alan Lawson famously notes that "the in between of the settlers is not unbounded space but a place of negotiation" (159) between "'mother' and 'other', simultaneously colonized and colonizing" (155). He also elaborates on the double inscription of the settler societies between the two First Worlds, where the settlers were caught between the empire on the one hand-hence the struggle for authenticity and authority through the adoption of the model of white civilityand the First Nations, who the settlers needed to displace, but not entirely replace, because then they would lose the Other by which to define themselves (154-58). ${ }^{3}$ Consequently, the persistence of borders was necessary; the frontier between the self and the other, the civil and the uncivil, had to exist in order to "signify the boundary of the self, to confirm the subjectivity of the invader-settler" (157), which relied on white civility.

Coleman further explains that the concept of civility in late nineteenth-century Canada was conflated with "a specific form of whiteness based on a British model of civility," and as such, white civility "has been naturalized as the norm for English Canadian cultural identity" (6). The concept of (British) ${ }^{4}$ white civility in Canada provided a grand narrative of the emerging and expanding Canadian nation which allowed the notions of progress, liberty, and law and order to be celebrated, while the means by which these were achieved were justified as necessary and/or marginalized in

3 See Coleman (15), where he rephrases Lawson's model for his own argument of white civility.

4 Throughout this article, I use the terms British and English interchangeably because of the way the notion of Englishness was transformed into the "pan-ethnic" (Coleman 17) concept of Britishness to give greater legitimacy to the different nations subsumed under Great Britain. The term, as Coleman explains, was coined by "Lowland Scots after the Treaty of Union in 1707 to manufacture a looser cultural identity that would represent them not as junior partners in the larger project of English imperialism but as senior members and equals" (17). Translated into the colonial context, the label of Britishness provided the different nations of the British Isles greater legitimacy in the invasion/settlement of colonies and the enforcement of white civility. 
the public view. The practices of inclusion and exclusion of peoples and events and of sanctions and incentives for the creation of the desired white anglophone civil society were selectively praised or suppressed in order to articulate the official mythopoeia of Canadian identity as white civility.

From the late twentieth century onwards, however, when official histories started to be renegotiated, this grand narrative was revealed as an "imposition of an imperial culture and that truncated indigenous history which colonialism has meant to many nations", as Linda Hutcheon (73) notes when speaking more broadly of the similarities between postmodern and postcolonial literatures. One such example is Guy Vanderhaeghe's novel The Last Crossing (2002), ${ }^{5}$ in which Vanderhaeghe tackles the issue of the official monologic history of the white settlement of the West in late nineteenth-century Canada. Vanderhaeghe offers a historical revision of the myth of the settlement of the West by exposing its underlying colonial ideology as "conceptually challenged, woefully lacking in vision" (372), as Len Findlay notes with regard to the broader issue of addressing and redressing colonialism. Vanderhaeghe exposes the deliberate blindness of colonialism effected by its strategies of isochronous approach to non-European and non-British societies and of the doctrine of the terra nullius. The novel's polyglot narrative, with its complex structure of juxtaposed narrators and framed narratives, includes the voices of white settlers of different nationalities, women, indigenous people, and English gentlemen. It zooms in on the grass-roots level of life in the locale of the Whoop Up country on the very fluid border between the British North-West Territories and the United States. With such a narrative structure, a very specific chronotope, and insight into historical circumstances of everyday life in the West, Vanderhaeghe's reinscription of history negotiates and juxtaposes "the once tyrannical weight of colonial history ... with the revealed local past" (Hutcheon 73). Starting from these premises, this essay will analyze the notion of blindness as the central metaphor of Vanderhaeghe's novel. Blindness will be examined on the level of individual characters and of society, this latter as colonial blindness, as a deliberate consequence of the blockage and erasure of that which was perceived as threatening or subversive to the dominant discourse of white civility.

On a basic level, The Last Crossing is a novel of quest or quests. In late nineteenthcentury Victorian England, the Gaunt family patriarch, a rich middle-class railway investor, sends two of his sons in search of his third son, Simon, who has gone missing in the vast spaces of Western North America. While one son, Charles, Simon's twin, is genuinely concerned about his brother, the other, Addington, sees the trip as

\footnotetext{
The Last Crossing is the second novel in Vanderhaeghe's so-called Western trilogy. The first was the highly acclaimed The Englishman's Boy (1996), and the third one was A Good Man (2011). By offering a pastiche of alternative histories, all three novels expose and deconstruct the myths and stereotypes of the Wild West and the frontier, the grand narratives of the settler history of the United States and Canada. All three are primarily historical novels, even if Vanderhaeghe sometimes calls them "literary westerns" (Vickers). The label of western is impossible to avoid when one situates the plot in the Western American landscapes in the second half of the nineteenth century, the chronotope of the Wild West.
} 
an adventurous expedition where he will play the explorer. After their journey across the Atlantic, the brothers arrive in Fort Benton, an outpost in the American West, where they hire a Métis scout, Jerry Potts, to help them in their search. The search party increases in number to include several other characters who are each on a quest of their own: Lucy Stoveall, the only woman in the party, is searching for her sister's murderer; Custis Straw, a well-to-do horse salesman pursues Lucy with the intention of marrying her; Aloysius Dooley, an Irish saloon-keeper, wants to ensure that Custis, his impulsive friend, does not spiral out of control. Even the search party's scout, Jerry Potts, a historical figure, who is half Kanai and half Scottish, is on a quest to reconcile (or try to survive) the two disparate halves of himself. To use Dooley's words, the search party is a veritable "game of fox and hounds" (Vanderhaeghe, The Last Crossing 120 ) in which each individual pursues another. In the party are also two hired hands and a journalist sycophant who is there to record Addington's "heroic" undertakings. The trail leads the party gradually westward and northward across the North American plains, and they freely cross the very fluid border between the United States and Canada in their wanderings from Fort Benton, in Montana, to Fort Edmonton, deep in the British North-West Territory. There the mystery of Lucy's sister's murder is solved and Simon is found. Eventually, only Charles returns to England; Simon refuses to leave North America, and Addington is killed in a bear-hunting accident.

The novel's narrative structure is complex, as there are three story-lines which constitute a Chinese boxes structure of time-space: the outermost narrative frame occurs in 1896 in London; the central plot occurs in 1871 in the Whoop-Up region in the border-area of future Montana and Alberta; and that plot is interspersed with memories of the Gaunt brothers' childhoods in England approximately two decades earlier. The narratorial role in the novel changes hands rapidly and dynamically, for there are four quite different first-person narrators (Charles Gaunt, Lucy Stoveall, Custis Straw, and Aloysius Dooley). There is also a third-person narrator with internal focalisation who switches focalizers, the technique offering a zoom-in and zoom-out of characters' consciousnesses and providing a view from the inside as well as the outside of each character. All of the narrators and focalizers possess a limited point of view, making them unreliable narrators, and their blindness and blind spots are often visible to other characters, who in turn are blind when it comes to their own biases and motivations.

In part, the inevitability of blindness in the novel can be explained by the extreme diversity of experiences and backgrounds of the ensemble of characters who journey together. Perhaps Lucy Stoveall, a pioneer, describes it best when, close to the end of the novel and her love affair with Charles Gaunt, she ruminates about her uncertain communication with Charles: "I understood how the signposts of each of our solitary roads can hardly be read by the other because they are so unlike. Sometimes Charles and me can scarce make out each other's speech. Him with his high-flown turns of phrase and his high-stepping words, me with my homely country talk, all knots to him that he can hardly pick apart" (Vanderhaeghe, The Last Crossing 319). Here the inability of mutual understanding, not for the lack of trying but due to differences in 
the worlds they inhabit, is brought forward through the medium of English. Mother tongue to both characters but so different for each of them due to their disparate backgrounds and experiences, as well as race, class, and gender, ${ }^{6}$ it engendered two different paroles to a single langue. Despite Lucy's awareness of the blind spots, she is incapable of enhancing her vision to overcome them, and she is aware that Charles can do so even less.

Blindness is additionally caused by the very different goals that guide characters in their actions. In fact, each character is so preoccupied with his or her own mission that it makes him or her biased and short-sighted with regard to outside circumstances and other personages: for example, Addington in his ego-mania sees others only as his pawns, Charles cannot understand Simon's desire to stay in the West, and Simon is oblivious to the world outside of his missionary zeal. Despite the thematic and narrative complexity of the novel, it is possible to discern a dominant trait, idea, or goal that rules each individual character to the point that they can be defined as flat characters (Forster 73). That is not to say that these characters" "personalities" are unconvincing; on the contrary, because of the force of their beliefs they are very impressive. And because of their singular focus, these characters are blind-both oblivious and deliberately blind - to alterity. As such, they are a useful means of exposing the fabrication behind the ideology of white civility with its related settler/invader official history and national myths of both Canada and the United States, which take the Western North-American spaces as their centre stage.

Connected to this, Lucy's words about the signposts on two solitary roads that "can hardly be read by the other because they are so unlike" (Vanderhaeghe, The Last Crossing 319) reiterate the novel's theme of crossing as only a temporary meeting of different individuals or cultures. As Patricia Linton observes, the "cultures intersect, but they are not contiguous or reconciled," because the crossing "is not analogous to the crossing of two plants to create a hybrid" (2). The encounters in the novel do not result in a productive cross-cultural crossing nor do they produce a viable example of hybridity in Homi Bhabha's sense of "the productivity of colonial power, its shifting forces and fixities" ("Signs Taken for Wonders" 154). In the novel, the colonial authority is represented as insisting on discriminatory strategies and clear binarism between "Europe and its Others, of colonizer and colonized, of the West and the Rest, of the vocal and the silent" (143), as Stephen Slemon notes in the larger context of postcolonial criticism. Hybridity is negated within the imperialist discourse that superimposes blindness - that is, lacunae and firm borders - over those places that produce the mixing of diverse cultures, histories, and civilizations. The impossibility of crossings on the story-level of the novel is counteracted by the revelation of the instability of colonial power that is always affected by the colonized subject, even though the imperial metropole "blinds itself to the reverse dynamic, the powers colonies have over their 'mother' countries" (Pratt 4).

The topics of gender, class, and race in this novel have already been discussed in detail in Linton and in Wyile; hence this article will not focus on them directly. 
In connection to this, Herb Wyile analyzes the ways in which Vanderhaeghe explodes the encounter of the Old-World Victorian society with the newly emerging North-American settler society, stereotypically perceived as order and civilization meeting anarchy. In Wyile's words, "Vanderhaeghe complicates not only the stereotype of the rectitude and propriety of Victorian England but also the stereotype of the licentious anarchy of the Wild West, suggesting how the former is not as honourable, nor the latter as dishonourable, as it has been made out to be" (61). According to Wyile, Vanderhaeghe invalidates this opposition by showing how the centre exports its excesses, personified in the crazed former military captain and violent killer Addington Gaunt, to the colonial margin of the emerging West. Addington abandons the thin veneer of "social surveillance and sexual regulation" (Wyile 61) that constrained him in England as he gives way to his egoism, and his obsessions with hunting and playing the explorer. While still in England, Addington enjoyed hunting and the thrill of the kill, as exemplified by his clandestine pleasure in poaching his father's cherished deer with a bow and arrow, but once in America, the veneer is shed and he pursues his own excesses, including the rape and murder of Lucy Stoveall's sister Madge. Through his character, the imperially imposed clear-cut boundaries between savagery and civilization — which maintain the difference and distance between the empire and the Other-are upturned, and the concept of the Western frontier, Turner's meeting point between savagery and civilization, is destabilized. As such, Addington represents the extreme invader and extreme case of blindness; however, he is unstoppable and unpunishable because he holds the position of ultimate power. Through the extremity of this character, Vanderhaeghe uncovers and invalidates the binary opposition of English civilization vs. New World anarchy, the dyad which the imperial centre uses as an argument for colonial expansion and which the emerging Canadian nation reinforces through the concept of white civility.

By upturning the received binaries of the dominant imperial discourse, and by grouping together divergent characters and their stories, Vanderhaeghe offers a crosssection of the complex political power games occurring in the relatively small territory of Whoop-Up country. Almost everyone in the group is a new arrival to the West: the Gaunts are English, Aloysius Dooley is Irish (there is mention of the Fenian raids into Canada), Lucy Stoveall is a dirt-poor Tennessean who ends up in the West because her husband goes to sell whisky to the Indians, Custis Straw is a Yankee in Fort Benton, a town populated by Southerners after the American Civil War. Jerry Potts, as the only native inhabitant of the group, is a synecdoche for the forced convergence of numerous indigenous peoples from across the North American lands into the confined space of the West due to the policing methods of civility, which for the Other included disease, starvation, forced relocation, and threat of extermination. In the larger context of the novel, Jerry Potts as a hybrid represents a (failed) potential towards a more productive meeting of cultures and a potential for intervention and ambivalence.

Speaking more broadly of Western Canadian authors as well as of Vanderhaeghe, Claire Campbell notes that Vanderhaeghe uses multiple stories and narrative strands to probe the received myths of the Old and New Worlds and to "expos[e] the artifice 
and authority in the arrangement of a linear, teleological order" of history (159). In other words, he foregrounds the emplotment strategies of history-making and mythmaking, revealing them as subjective, selective, and arbitrary, and therefore as no different from the narrative techniques used in fictional texts. In this way, Vanderhaeghe urges readers to question the veracity of the received historical accounts and "to contemplate and examine the making of history in all its various manifestations" ("History and Fiction" 430). Instead of the received dominant narratives, Vanderhaeghe offers an alternative way of writing history which establishes "a past for the West that could correct (if not replace) its endemic characterization as a frontier" (Campbell 152). He dismantles the myths of the West as 'the manifest destiny' and the cradle of the American nation, and of the Canadian North-West Territories as the cradle of "law and order," where Canadian law and the North-West Mounted Police (later the Royal Canadian Mounted Police) supposedly maintained civilized and protective relationships with indigenous peoples. What is more, Vanderhaeghe deliberately situates the plots of both The Englishman's Boy and The Last Crossing - two novels of his Western Trilogy_-in the period before the North-West Mounted Police was established in order to further underline the lawless foundation on which the ideological foundation of the myth of "law and order" was later fabricated. These nation-making myths of success are more realistically replaced with failure because, as Arnold Davidson explains, the "expected epic of victory ... gives way to an epic of loss-what the Indians lost, what the Métis lost, and what the prevailing whites lost, too, through those two other losses" (22-23). In The Last Crossing, this is perhaps best seen in the character of Charles Gaunt, who personifies this failure despite his position of power in the imperial hierarchy: in him is concentrated the colonial ideology enforced by the British and mimicked by the Canadians on the Western territory of future Canada. Out of the three brothers he is the only one who returns to England and who remains, at the end of the novel, the last of his English family line.

Charles is portrayed as the English upper-middle-class gentleman who has not inherited his father's lower-class cunning and entrepreneurial spirit and who is governed by inactivity coupled with post factum regret for missed opportunities. He deludes himself that he is a talented painter, but none of his paintings are finished because he lacks vision. He is so tied down by conformity that he cannot exit his often selfrighteous shell, and his twin, Simon, in their crucial confrontation, tells him he never scratches beneath the surface of things (Vanderhaeghe, Last Crossing, 203). As such, he is reminiscent of a type in Margaret Atwood's 1972 study of Canadian literature, that of the paralyzed artist. Charles's paralysis is obvious in his impotence as a painter and in his penchant for introspection that does not, however, penetrate the blind spots of his own personality. As an artist, in Atwood's formulation, Charles has a choice to "stay in the culture and be crippled as an artist; or escape into nothing" (189). If he who is "frozen, paralyzed" chooses escape, "does flight unfreeze him?" (190). Flight does indeed unfreeze Charles, for after the Canadian experience he leaves England for a while, fleeing "the culturally unhealthy climate" (188). He goes to Italy, where he sheds his conformity and consequently is able to create art. His fame as an artist 
comes late in life, ironically not from painting but from a collection of love poetry written in homage to an idealized Lucy.

While in Atwood's typology Canada is the culturally barren country, in The Last Crossing that role belongs to England, where Charles produces no heir either biologically or artistically. However, during his stay in Italy, he "fathers" a collection of poetry, and in Canada, unbeknownst to him until the very end of the novel, he has fathered a daughter with Lucy. In this manner, English culture and society are shown to be "dead" and "inaccessible" (Atwood 184), but there is hope for life and artistic production outside of England. The margin has, in a manner of speaking, survived the centre, branching off from the dried-up trunk into a new entity that needs to acknowledge its own past blindness and failures in order to gain self-awareness and move into the present.

And while the ending of the novel holds a certain open-ended promise for Charles, in the majority of the novel his paralysis causes him to suffer from both claustrophobia and "fear of the 'outside" (Atwood 184). Claustrophobia is in Charles caused by his conformity and Englishness. His fear of the "outside" manifests itself as incomprehension and unacknowledged fear of the $\mathrm{O} /$ other, and in the novel, it works on two levels: as dislocation, where the other/"outside" is the new land which he cannot read because it is too different from England. But the "outside" is also the outside of his self: namely, his twin, Simon, who should stereotypically be his mirror-image and yet is his unknowable other. Even as an adult, Simon has always been "as innocent as he was at ten, oblivious to other's opinions" (Vanderhaeghe, The Last Crossing 111) and Charles, ever a conformist, cannot comprehend Simon's turning a blind eye to the norms of his societal rank and Simon's wish to become a missionary in the American West.

The crux of Charles's incomprehension of the other occurs when, close to the end of the novel, Simon is discovered in a Crow camp near Fort Benton. During his search, Charles imagines Simon helpless, lost, and marooned in the wilderness, but instead finds him in a Crow camp living with a bote, an indigenous person who represents "the mystery of two spirits in one body," a person who is "holy, a creature both male and female, yet more than either" (Vanderhaeghe, The Last Crossing 355). Once he learns that the bote is biologically a man, Charles cannot accept the impropriety of Simon's relationship, which he is predetermined to read as homosexual. Yet even while he still believes that the bote is a woman, he tries to persuade Simon to move to Fort Benton with his "country wife," to the community of white men. Charles absolutely dismisses both Simon's wish to remain where he is and his, as Charles phrases it, "willingness to sacrifice himself for primitives who never asked for his help, or could be improved by it" (Vanderhaeghe, The Last Crossing 108). Charles's disparaging tone demonstrates his belief that "things ought to fall into place just because he want[s] them to" (Vanderhaeghe, The Last Crossing 354), by which he mirrors the colonizer's firm belief in his inherent power in the colonies. When he realizes he is not going to succeed in changing Simon's mind, Charles "act[s] as a man is liable to do when everything he wants is thwarted. Now he's throwing all his energy into doing what he 
can do to avoid facing what is outside his power to accomplish" (Vanderhaeghe, The Last Crossing 356). In other words, Charles cannot cope with the possibility that his wishes will not be heeded, and yet he is eventually forced to leave the West without his brother because Simon's tenacity matches his own. Charles's deliberate blindness to alterity is absolute and reflective of the colonizing ideology: he sees only cultural difference and not cultural diversity in Bhabha's sense of the terms ("The Commitment to Theory"), and he absolutely refuses to accept any culture, opinion, or belief other than his own.

The taboo of homosexuality is the breaking point for Charles where he must admit defeat. Interestingly, both Linton and Wyile read Simon and the bote's union as homosexual and consequently interpret Simon's decision to leave the heteronormative British and North American cultures as necessary in order to live out his homosexuality freely. However, there is another possible reading of the union between the bote and Simon. It can be read as asexual. This reading is corroborated by Simon's "Christian idealism" (Vanderhaeghe, The Last Crossing 353) and his unswerving missionary zeal. Simon sees his rescue by the bote as God's plan with himself cast as a saintly figure among the people he is sent to Christianize. When Charles first visits, Simon tells him of a prophetic dream that is as parabolic as the Pharaoh's dream from the Book of Genesis: it is a dream presaging Charles's arrival in which he sees Charles as a blind horse with glass buttons for eyes who, in its endless hunger, tears into Simon's and the bote's lodge (Vanderhaeghe, The Last Crossing 352). Simon, furthermore, describes himself to Charles as shedding the natural body and embracing the spiritual one (Vanderhaeghe, The Last Crossing 350), quoting a verse from Corinthians which speaks about resurrection. It can be argued, therefore, that his union with the bote is entirely spiritual and not physical, for in the novel there is no mention of sexuality with regard to Simon, while it is quite openly mentioned with regard to other characters. On the contrary, Simon's behaviour toward the bote is described as that of a benevolent father or brother-very Christ-like. The analogy with Christianity and Simon's vision of himself as saintly does not stop here: having rescued Simon, the bote has claimed him, but the bote has also adopted an orphaned child, so their small community could be said to mimic the Christian holy family deep in the bush.

The argument regarding Simon's putative homosexuality is relevant only with regard to the ways in which said homosexuality is interpreted by different characters in the novel, reflecting divergent viewpoints in white and indigenous cultures. First of all, neither Charles nor Custis nor Potts are able to comprehend Simon's relationship outside of the frame of sexuality despite their different cultural backgrounds. This is their shared blind spot. But since Charles is determined to remove Simon from the Crow camp and relocate him to Fort Benton, both Custis and Potts offer Charles stories reflecting two different outlooks on homosexuality. In order to open Charles's eyes with regard to the bote's sex, Custis delivers a story about a pair of soldiers living in Fort Benton as man and wife and the town's derision when they are found out, indicating the impossibility of a homosexual union in a western-based society. He also offers another story to explain the bote's holy status within indigenous societies. Potts 
follows Custis's second story by underlining how important it is for the Two Spirit to follow his/her dual nature, and the relevance s/he has in the community as auspice of good fortune. The indigenous stories offer a counter-narrative to the white one illustrating a different conception of genders in indigenous cultures. Potts's story confirms Walter Williams's theory that "Indians have options not in terms of either/or, opposite categories, but in terms of various degrees along a continuum between masculine and feminine" (Williams 80). A bote or Two Spirit is considered to be a holy person, a spiritual leader, his/her position "an established social category fully integrated with other sanctioned social identities" (Linton 3) and as such not taboo. Despite the two different worldviews offered to Charles, Charles is only able to comprehend one of them because he dismisses the relevance of a culture and beliefs that are not his own.

And while it may appear that Simon in his nonconformity disregards white society's notions of race, class, and gender, possessing instead a more liberal mindset, his actions reveal that he is the same as the other characters in the novel, blinded by his missionary (and colonial) zeal. Simon sees the bote as a paragon of charity (Vanderhaeghe, The Last Crossing 353), one of the three fundamental concepts of Christianity. He has converted the bote to Christianity and has effectively cut her/him off from his/her own indigenous traditions and her/his very important role in the indigenous community. In his missionary zeal, he perceives this act as the salvation of the race because he is taking "the message of Jesus to [Indians] with the utmost respect" (Vanderhaeghe, The Last Crossing 218). His blindness is most obvious in the word "respect," which Simon believes to be his to dispense to the community. However, by Christianizing the bote he has superimposed his set of beliefs over indigenous ones, reiterating the colonial mission of white civility: enlightenment and Christianization. Simon is stratifying societies and beliefs, and in a manner identical to Charles's, he does not accept alterity. His underlying imperial upbringing is merely shrouded in humility and Christian mission, all the while perpetuating "the idea of civility as a (White) cultural practice" (Coleman 12). His actions, predictably, bring forth hostility and instability within the tribe, and it remains an open question as to how long the bote will be able to protect Simon from the tribe's retaliation. The concept of white civility, as formulated in Potts's observation that "[n]othing exists for white men unless they give it a name in their own language," and "[o]nce they give a name to a thing, they think that is enough to understand it" (Vanderhaeghe, The Last Crossing 98), successfully encapsulates this unilateralism in the contact of cultures. Consequently, the bote is labelled as homosexual, indigenous societies as savage, indigenous peoples as wild men in need of salvation or destined for extinction. Both Simon's and Charles's blindness represent a gap between what they want to see and what is "outside"/other-a cultural and semantic gap between that which can be described by white culture/language and that which does not possess a label in English (even "Two Spirit" is a misnomer) and is therefore dismissed as non-existent or inconsequential.

However, Vanderhaeghe shows that the concept of white civility is not as easily applicable to the ideology of colonialism as it may appear at first sight. By juxtaposing two views of white civility in Fort Edmonton—one from the white inhabitants 
of Fort Edmonton and the other from Charles, who is a newcomer to this outpostVanderhaeghe reveals the problematic nature of the concept and the ideology behind it. Charles's first impression of Fort Edmonton is that it is "a sterling testimony to British commerce and industry," but soon he starts wondering whether "this place bears less resemblance to Manchester than it does to some Roman outpost huddled forlornly on the periphery of the Empire, a polyglot and bastard village" (Vanderhaeghe, The Last Crossing 281). Charles also notes that the chief factor and his men "feel themselves as exemplars of everything British and are blissfully unaware that we visitors from the "Old Country" soon conclude the barbarians have had greater influence on the character and habits of their rulers than the rulers on their subjects" (Vanderhaeghe, The Last Crossing 282). Charles's observation from the outside offers an insight into the blindness of those within. The chief factor and his subalterns live within the garrison: in their isolated and forlorn outpost, they are separated from the culture of the centre, huddled into a garrison, the epitome of Northrop Frye's "garrison mentality," "confronted with a huge, unthinking, menacing, and formidable physical setting" (225). They can rely only on themselves for "distinctively human values" (ibid.), that is, white civility. Fearing "contamination" by the indigenous other, they abide by the imperial concept of the colonial frontier, which on the one hand "implies not only a hierarchy of colonizer (European and political centre of power) over colonized (non-European and marginal) but, more importantly, a one-way process of influence in which the colonizer remains immune from any contact with the colonized" (Grace 14). ${ }^{7}$ Formulated in such a way, the concept of the colonial frontier promotes a sense of security in the inhabitants of the garrison through the (illusory) assurance of a firm hierarchy in the colonies as well as of immunity from "going native."

However, Vanderhaeghe shows on the example of Fort Edmonton that the idea of firm boundaries between the British within the garrison and the indigenous peoples outside of it is only an illusion. Instead of the colonial frontier, Fort Edmonton is a contact zone that exists out there on the colonial margin. Mary Louise Pratt famously defines the contact zone as "the space in which peoples geographically and historically separated come into contact with each other and establish on-going relations, usually involving conditions of coercion, radical inequality, and intractable conflict" (6). Despite the inequality of power relations, the process of cultural exchange occurs because contact between cultures occurs. The boundary between the colonizer and the colonized is more porous than the imperialist ideology allows, but the chief factor and his men are blind to this reality because they do not have a reference point to measure their degree of deviation from the centre. It takes someone from the centre looking onto the margin to reveal their blindness.

It is interesting to observe what happens to the binary of wilderness vs. civilization once Charles notices that "the barbarians have had greater influence on the character and habits of their rulers than the rulers on their subjects" (Vanderhaeghe, The Last

Sherrill Grace discusses the concept of the colonial frontier with regard to Vanderhaeghe's novel The Englishman's Boy, but the concept can be applied equally well to The Last Crossing. 
Crossing 282). Charles correctly identifies that, in Fort Edmonton, the binary has collapsed, but his interpretation does not lead to the binary's invalidation and erasure. On the contrary, Charles's use of descriptors such as "bastard," "polyglot," and "barbarians" reveals that he has remapped the binary to exclude the contaminated white men, shifting the binary's boundary closer to the centre. With his elitist view, Charles now performs the othering of the Hudson's Bay Company men of Fort Edmonton. In this way, Vanderhaeghe shows how the garrison mentality "renders explicit the colonial urge to seek protection against intrusions from the outside and, simultaneously, the reluctance to tolerate excursions beyond prescribed limits" (Omhovère 90). Imperialist ideology, in its unwillingness to tolerate transgression, programmatically introduces another blind spot into the paradigm of the margin first by establishing a stratification within whiteness and then by removing those members who violate its principles, that is, the code of white civility. Instead of exploring the potential of such cross-cultural contact, Charles, as the representative of the imperial centre, needs to defend its illusory "cultural purity and authenticity" (94), as Donna Brydon argues in the context of contamination as a cultural and political project of postmodernism and postcolonialism.

The Hudson's Bay Company men, disavowed by Charles as contaminated and parodying imitations of white civility, are in fact examples of settler society, situated in Lawson's "liminal sites at the point of negotiation between the contending authorities of Empire and Native" (155). As examples of hybridity, they point more broadly to the fact that "colonial presence is always ambivalent, split between its appearance as original and authoritative and its articulation as repetition and difference" (Bhabha, "Signs Taken for Wonders" 150). They expose "the necessary deformation and displacement of all sites of discrimination and domination" (154) that Charles cannot acknowledge for fear of destabilizing the colonial power and consequently white civility.

This rigid colonial distinction between self and Other imposed by Charles and, more broadly, by the colonial power is further destabilized in the novel by Jerry Potts, a historical figure who was the epitome of "the crossing" in the American NorthWestern spaces around the $49^{\text {th }}$ parallel. He is a product of the contact zone who personifies hybridity and its potential but also the results of its negation. ${ }^{8}$ The novel juxtaposes the "sentimental myth" of Jerry Potts "as genuinely hybrid, successfully crossing racial and cultural boundaries" (Linton 6) with the complexity and limitations of such a hybrid life in late nineteenth-century Western landscapes. Half Scottish and half Kanai, Potts is historically referred to as a "half-breed," neither one nor the other, "defined by a lack of identity" (Linton 6). Within the imperialist setup, he is not allowed to have both racial identities; his hybrid identity is used pejoratively to emphasize the negative aspects of racial impurity. ${ }^{9} \mathrm{He}$ cannot be accommodated into the dominant narrative because he is seen as subversive. As a consequence, in the

8 For a detailed analysis of Jerry Potts, see Linton and Wyile.

9 See Young. 
dominant discourse, his narrative becomes riddled with blind spots as the colonizing culture turns him into a sentimental illusion that glosses over those aspects of his life which are deemed subversive to colonial ideology. The emphasis is placed, instead, on those elements of Potts's life-a great scout, a guide of the North-West Mounted Police on the Plains-that reinforce the dominant narrative of white settlement.

The complexity of Potts's in-between status does not end here, however. As Linton explains, in The Last Crossing Potts is unable to realize his hybrid nature. His wish "to be both" (Vanderhaeghe, The Last Crossing 105) Scottish and Kanai is impossible, but he blindly persists in this desire until the end of the novel, when he is reconciled to the fact "that to live life divided is dangerous, a confusion that sickens the spirit" (Vanderhaeghe, The Last Crossing 100). He then realizes that he needs to choose between either/or because in the imposed colonial circumstances there is no option to choose both-and. ${ }^{10}$ However, Linton argues that, in the context of the novel, his narrative is "mitigated in two ways" (Linton 7): first, all of the characters in the novel try to survive their circumstances as best they can, and in this sense, Potts's story does not stand out too starkly from other individual destinies. Second, claims Linton, "Potts (in Vanderhaeghe's representation) sees the impossibility of a hybrid social identity not as the specific denial of him and others like him by Euro-American culture but as the way of the world" (7). He is denied the choice of hybridity in both native and white cultures, so there is no possibility of reconciliation between the different aspects of his self. Like the other characters in The Last Crossing, he is unable to realize the crossing, but he does, however, function as a symbol of hybridity. He is shown as a potential that is not exploited, a crossing made impossible in the context of that political makeup.

Thus, in The Last Crossing Vanderhaeghe shows the inability of crossing, of making connections and relationships between the white and the Other within the colonial ideology that dominated nineteenth-century Canada. Vanderhaeghe shows that, as Slemon famously notes in a slightly different context but regarding postcolonial and anti-colonial literature, "the binarism of Europe and its Others, of colonizer and colonized, of the West and the Rest, of the vocal and the silent" (143) is an ideological illusion. Myths of "manifest destiny," "law and order," and white civility are in the novel exposed as myths; gender binaries break down in the bote; racial binaries break down in the Métis character of Jerry Potts; and Charles Gaunt exemplifies the porousness of the contact zone in his own flight from the empire and its rigidity. Vanderhaeghe's novel, as a "re-historical fiction" (Slemon 148), shows the awareness of complicity that the postcolonial settler culture brings to sight as a counter-discourse to the grand narrative of white civility.

${ }_{10}$ Cf. Linton 6. 


\section{Works Cited}

Atwood, Margaret. Survival: a Thematic Guide to Canadian Literature. House of Anansi P, 1972.

Bhabha, Homi. K. "Signs Taken for Wonders: Questions of Ambivalence and Authority under a Tree outside Delhi, May 1817." Critical Inquiry, vol. 12, no.1, Autumn 1985, pp. 144-65.

- . "The Commitment to Theory." new formations, no. 5, Summer 1988, pp. 5-23.

Brydon, Diana. "The White Inuit Speaks: Contamination as Literary Strategy." Unhomely States: Theorizing English-Canadian Postcolonialism, edited by Cynthia Sugars. Broadview P, 2004, pp. 94-106.

Campbell, Claire. "To Free Itself, and Find Itself': Writing a History for the Prairie West." National Plots, Historical Fiction and Changing Ideas of Canada, edited by Andrea Cabajsky and Brett Joseph Grubisic. Wilfrid Laurier UP, 2010, pp. 151-66.

Coleman, Daniel. White Civility: The Literary Project of English Canada. U of Toronto P, 2006.

Davidson, Arnold E. Coyote Country: Fictions of the Canadian West. Duke UP, 1994.

Endicott, Marina. "Guy Vanderhaeghe's The Last Crossing." Arts \& Opinion, vol. 1, no. 1 (2002), www.artsandopinion.com/2002_v1_n1/endicott.htm. Accessed 14 April 2015.

Findlay, Len. "Always Indigenize! The Radical Humanities in the Postcolonial Canadian University." Unhomely States: Theorizing English-Canadian Postcolonialism, edited by Cynthia Sugars. Broadview P, 2004, pp. 367-82.

Forster, E. M. Aspects of the Novel, Penguin Books, 1990.

Frye, Northrop. The Bush Garden: Essays on the Canadian Imagination. House of Anansi P, 1971.

Grace, Sherrill. "Calling Out the McLean Boys: George Bowering's Shoot and the Autobiography of British Columbia History." Canadian Literature, no. 184, Spring 2005, pp. 11-25.

Grgas, Stipe. Ispisivanje prostora: čitanje suvremenoga američkog romana. Naklada MD, 2000.

Hutcheon, Linda. "Circling the Downspout of Empire': Post-Colonialism and Postmodernism." Unhomely States: Theorizing English-Canadian Postcolonialism, edited by Cynthia Sugars. Broadview P, 2004, pp. 71-93.

Lawson, Alan. "Postcolonial Theory and the 'Settler' Subject". Unhomely States: Theorizing English-Canadian Postcolonialism, edited by Cynthia Sugars. Broadview P, 2004, pp. 151-64.

Linton, Patricia. "Subaltern Identity in Guy Vanderhaeghe's The Last Crossing." STAR (Scotland's Transatlantic Relations) Project Archive, 2004, pp. 1-9, www.star.ac.uk/ archive/Papers/Linton_TheLastCrossing.pdf. Accessed 14 April 2015. 
Omhovère, Claire. "Out of the Garrison and Beyond: The Rewriting of the Landscape Tradition in Contemporary Canadian Fiction." Reflective Landscapes of the Anglophone Countries, edited by Pascale Guibert. Rodopi, 2011, pp. 85-104.

Pratt, Mary Louise. Imperial Eyes: Travel Writing and Transculturation. Routledge, 1992.

Slemon, Stephen. "Unsettling the Empire: Resistance Theory for the Second World." Unhomely States: Theorizing English-Canadian Postcolonialism, edited by Cynthia Sugars. Broadview P, 2004, pp. 139-50.

Turner, Frederick Jackson. The Frontier in American History. The U of Arizona P, 1994.

Vanderhaeghe, Guy. "History and Fiction." Canadian Journal of History/Annales canadiennes d'histoire, vol. XL, December 2005, pp. 429-30.

—. The Last Crossing. Emblem Editions, McClelland \& Stewart, 2003.

Vickers, Salley. "Horse sense in the West." The Guardian, 15 Feb 2004, www.theguardian.com/books/2004/feb/15/fiction.features1. Accessed 21 April 2015.

Williams, Walter L. The Spirit and the Flesh, Sexual Diversity in the American Indian Culture. Beacon P, 1986.

Wyile, Herb. "Doing the Honourable Thing: Guy Vanderhaeghe's The Last Crossing." Canadian Literature, no. 185, Summer 2005, pp. 59-74.

Young, Robert R. C. Colonial Desire: Hybridity in Theory, Culture and Race. Routledge, 1995. 